Chronic Obstructive Pulmonary Diseases: Journal of the COPD Foundation

Review

\title{
The Beneficial Effects of Antioxidants in Health and Diseases
}

Sabina Janciauskiene, PharmD, $\mathrm{PhD}^{1}$

\section{Abstract}

Reactive oxygen and nitrogen species can be generated endogenously (by mitochondria, peroxisomes, and phagocytic cells) and exogenously (by pollutions, UV exposure, xenobiotic compounds, and cigarette smoke). The negative effects of free radicals are neutralized by antioxidant molecules synthesized in our body, like glutathione, uric acid, or ubiquinone, and those obtained from the diet, such as vitamins C, E, and A, and flavonoids. Different microelements like selenium and zinc have no antioxidant action themselves but are required for the activity of many antioxidant enzymes. Furthermore, circulating blood proteins are suggested to account for more than $50 \%$ of the combined antioxidant effects of urate, ascorbate, and vitamin E. Antioxidants together constitute a mutually supportive defense against reactive oxygen and nitrogen species to maintain the oxidant/antioxidant balance. This article outlines the oxidative and anti-oxidative molecules involved in the pathogenesis of chronic obstructive lung disease. The role of albumin and alpha-1 antitrypsin in antioxidant defense is also discussed.

\footnotetext{
Abbreviations: reactive oxygen species, ROS; nicotinamide adenine dinucliotide phosphate hydrogen, NADPH; reactive nitrogen species, RNS; chronic obstructive pulmonary disease, COPD; manganese, Mn; Mn superoxide dismutase, MnSOD; nuclear factor erythroid-2related factor, Nrf2; lipopolysaccharide, LPS; Beta-Carotene and Retinol Efficacy Trial, CARET; forced expiratory volume in 1 second, FEV1; myeloperoxidase, MPO, superoxide dismutase, SOD; cytoplasmic Cu-ZnSOD, SOD1; mitochondrial MnSOD, SOD2; glutathione peroxidases, GPXs; peroxiredoxins, Prxs; N-acetylcysteine, NAC; glutathione, GSH; coenzyme Q10, CoQ; uric acid, UR; human serum albumin, HAS; alpha-1 antitrypsin, AAT; methionine, Met; alpha-1 antitrypsin deficiency, AATD; endoplasmic reticulum, ER; all-trans retinoic acid, ATRA

Funding Support: This study was supported by the National Science Center, Poland (grant 2015/17/B/NZ5/01370).

Date of Acceptance: December 13, 2019

Citation: Janciauskiene S. The beneficial effects of antioxidants in health and diseases. Chronic Obstr Pulm Dis. 2020;7(3):182-202. doi: https://doi.org/10.15326/jcopdf.7.3.2019.0152
}

1 Department of Respiratory Medicine, Hannover Medical School, Member of German Centre for Lung Research (DZL), Hannover, Germany; Department of Genetics and Clinical Immunology, National Institute of Tuberculosis and Lung Diseases, Warsaw, Poland

\section{Address correspondence to:}

Sabina Janciauskiene, PharmD, PhD

Phone: +495115327297

Email: janciauskiene.sabina@mh-hannover.de

\section{Keywords:}

alpha-1 antitrypsin; reactive oxygen species; oxidative stress; antioxidants, inflammation; lung disease

\section{Reactive Oxygen Species}

Cellular respiration consists of 3 main processesglycolysis, the citric acid cycle, and oxidative phosphorylation-which require free oxygen. The conversion of oxygen $\left(\mathrm{O}_{2}\right)$ into cellular energy involves its reduction to $\mathrm{H}_{2} \mathrm{O}$ by accepting 4 electrons. Oxygen by itself has low reactivity; however, it can undergo a series of one electron reductions and produce reactive intermediates. Approximately 5\% of the inhaled $\mathrm{O}_{2}$ is converted to reactive oxygen molecules with an unpaired number of electrons such as hydroxyl ( $\mathrm{OH} \cdot)$, superoxide anion $\left(\mathrm{O}_{2}^{-\cdot}\right)$, hydrogen peroxide $\left(\mathrm{H}_{2} \mathrm{O}_{2}\right)$, oxygen singlet $\left(\mathrm{O}_{2}\right)$, hypochlorite $\left(\mathrm{OCI}^{-}\right)$, nitric oxide (NO), and peroxynitrite $\left(\mathrm{ONOO}^{-}\right)$radicals. ${ }^{1}$ The 
external sources of reactive oxygen species (ROS) are cigarette smoke, environmental pollutants, radiation, certain drugs, pesticides, industrial solvents, and ozone. The endogenous sources of oxidants include cellular systems localized on the plasma membrane, in the cytosol, in the peroxisomes, and on membranes of mitochondria and endoplasmic reticulum. ${ }^{2}$ The main sources of cellular ROS are mitochondria and nicotinamide adenine dinucleotide phosphate (NADPH) oxidases, and peroxisomes containing xanthine oxidase and the inducible form of nitric oxide synthase, which produce superoxide anion and nitric oxide, respectively. ${ }^{3}$ In addition, the activation of phagocyte heme peroxidases, like myeloperoxidase, results in the formation of the potent oxidants. Cellular thiols, hydroquinones and catecholamines can undergo redox reactions and contribute to intracellular ROS production as well. Pathogens, such as Pseudomonas aeruginosa that release pyocyanin, a nitrogen-containing aromatic compound, can also increase intracellular levels of superoxide and hydrogen peroxide. ${ }^{4}$

The chemically reactive radicals are generated internally by oxidant enzymes, phagocytic cells, arachidonate pathways, and exercise. Low levels of ROS play essential roles in microbe killing and act as secondary messengers for intracellular signaling pathways involved in host immune responses. ${ }^{5,6}$ For example, free radicals play a role in detoxification of xenobiotics by oxidizing enzymes, in killing of microorganisms by macrophages and cytotoxic lymphocytes, and in the generation of prostaglandins and leukotrienes, which activate oxygenases (e.g., cyclooxygenases and lipoxygenase) and thus act as modulators of the inflammatory response.

Among the ROS, hydroxyl is the most reactive radical, which reacts with lipids, proteins, nucleic acids, and carbohydrates. The hydroxyl radical induces the formation of DNA-protein cross-links, singleand double-stranded breaks, lipid peroxidation, and protein fragmentation. ${ }^{7}$ For example, polyunsaturated fatty acids are among the most susceptible targets of hydroxyl radicals. ${ }^{8}$

Nitric oxide (NO) normally activates soluble guanylate cyclase, to act as a neurotransmitter and blood pressure regulator. Nitric oxide also plays a role in iron trafficking because it mimics the consequences of iron starvation and triggers iron uptake by cells. ${ }^{9}$ During pathological states, reaction between nitric oxide and superoxide can generate highly reactive peroxynitrite $\left(\mathrm{ONOO}^{-}\right)$radicals, which are implicated in lipid peroxidation. Another damaging nitrogen radical, nitrogen dioxide $\left(\mathrm{NO}_{2}\right)$, is formed during atmospheric dioxide pollution and cigarette smoking. ${ }^{10}$ $\mathrm{NO}$ and its by-products, such as nitrate $\left(\mathrm{NO}^{-}\right)$, nitrite $\left(\mathrm{NO}_{2}{ }^{-}\right)$, peroxynitrite $\left(\mathrm{ONOO}^{-}\right)$, and 3-nitrotyrosine are called reactive nitrogen species (RNS). The RNS play a role in cellular signaling, vasodilatation, and immune response. ${ }^{11}$

\section{Chronic Obstructive Pulmonary Disease and Reactive Oxygen Species}

Lungs are particularly vulnerable to oxidative stress due to the high oxygen environment and exposure to environmental pathogens and oxidants. For example, a single puff of cigarette smoke estimated to have about $1 \times 10^{15}$ oxidant molecules. ${ }^{12}$ Smoking and air pollution are the most significant risk factors for chronic obstructive pulmonary disease (COPD) development, which attribute to oxidative and carbonyl stress. ${ }^{13}$ The increased burden of reactive oxidants in patients with COPD also derives from leukocytes and macrophages involved in the inflammatory process in the lungs. ${ }^{14}$ The ROS and RNS can cause oxidative damage to DNA, lipids, carbohydrates and proteins, and thereby mediate an array of downstream processes that contribute to the development and progression of COPD. They also activate resident cells in the lung, particularly epithelial cells and alveolar macrophages, to generate chemotactic molecules that recruit neutrophils, monocytes and lymphocytes into the lung. ${ }^{15}$ Collectively, these events lead to a vicious cycle of persistent inflammation and chronic oxidative stress, which results in protease-anti-protease imbalance, defects in tissue repair mechanisms, accelerated apoptosis in lung cells and progression of COPD. ${ }^{16}$

Dysregulated mitochondrial ROS production is a feature of smokers with COPD ${ }^{17,18}$ that is not limited to the lungs. For example, Belchamber et al reported mitochondrial dysfunction in COPD macrophages. ${ }^{19}$ Other studies found that mitochondrial-targeted antioxidant treatment reduces proliferation and cytokine production of airway smooth muscle cells of patients with COPD. ${ }^{20}$ Oxidative stress involved in 
pathogenesis of COPD is not just the result of increased burden of oxidants but also a decreased anti-oxidative potential. $^{21}$

\section{Antioxidants and Oxidative Stress}

To protect human cells and organ systems against free radicals, a complex antioxidant system exists. Dietary and endogenous enzymatic and nonenzymatic antioxidants counteract the damaging effects of free radicals by various mechanisms, such as electron donation, catalytic removal, or binding radicals and/or gene expression regulation. ${ }^{22}$ Together, antioxidants constitute an integrated defense against ROS (Figure 1). Only when the production of free radicals overwhelms the antioxidant defense and the oxidant/ antioxidant imbalance shifts in favor of oxidants, does oxidative stress develop.

Oxidative stress is a part of many acute and chronic pathological processes in respiratory, cardiovascular, kidney, neurodegenerative, and biliary diseases, as well as in cancer. Oxidative stress is also associated with cellular senescence and aging. ${ }^{23}$ Age-related oxidative stress affects the nervous, endocrine, and immune systems and may create a vicious cycle involving chronic oxidative stress and inflammation, which support each other, and increase age-related morbidity and mortality. ${ }^{24}$

\section{Dietary Antioxidants}

\section{Vitamins and Minerals}

Fruits and vegetables contain antioxidant vitamins, including vitamin $C$, vitamin $E$, and pro-vitamin A carotenoids, activities of which have been wellstudied. Antioxidant vitamins are present on the cell membrane, intracellularly, or extracellularly, and react with free radicals to either remove or inhibit them. ${ }^{25}$ Vitamin $E$ is the major peroxyl radical scavenger, ${ }^{26}$ whereas carotenoids quench singlet oxygen and inhibit lipid peroxidation. ${ }^{27}$ Vitamin $C$ acts as a ROS scavenger and thus can rescue vitamin $\mathrm{E}$, which is anchored in the cell membrane and prevents lipid peroxidation. $^{28,29}$ Koike et al reported that treatment with vitamin C prevented cigarette smoke-induced emphysema and restored lung tissue damage in protein-30 knockout (SMP30-KO) mice characterized by accelerated aging. ${ }^{30}$

Selenium, copper, manganese, and zinc are considered antioxidant minerals because they are required for the activity of antioxidant enzymes. For example, selenium is required for the activity of glutathione peroxidases, which are scavengers of hydrogen peroxide in subcellular compartments. ${ }^{31}$ Notably, lower levels of serum selenium were reported in an elderly Swedish population relative to other European regions. Furthermore, people in the lowest

\section{Figure 1. Main Endogenous and Dietary Antioxidants}

\begin{tabular}{|c|c|}
\hline & Eain antioxidants \\
\hline Non-enzymatic & Enzymatic \\
Melatonin, Polyamines & Superoxide dismutases \\
Uric acid, Bilirubin & Catalases \\
Plasma proteins & Carotenoids \\
\hline
\end{tabular}


selenium quartile $(<57.2 \mu \mathrm{g} / \mathrm{L}$ ) were found to have an increased mortality, suggesting the value of selenium supplementation. ${ }^{32}$

Zinc acts as a cofactor for enzymes of the antioxidant system, and inhibits the enzyme, nicotinamide adenine dinucleotide phosphate oxidase, a prooxidant enzyme, and induces metallothionein synthesis, which is important in the reduction of hydroxyl radicals. ${ }^{33}$

Manganese $(\mathrm{Mn})$ is one of the required components for $\mathrm{Mn}$ superoxide dismutase (MnSOD), which is responsible for scavenging $\mathrm{ROS}$ during mitochondrial oxidative stress. In addition, $\mathrm{Mn}$ is involved in the synthesis and activation of many enzymes and in the regulation of glucose and lipid metabolism. ${ }^{34}$ It is important to note that the antioxidant properties of $\mathrm{Mn}$ are outcompeted by cellular iron binding to MnSOD, so iron may counteract the benefits of manganese antioxidants. ${ }^{35}$ Because a number of bacterial proteins are $\mathrm{Mn}$ dependent, host-mediated $\mathrm{Mn}$ sequestration has the potential to disrupt bacterial pathogenesis. ${ }^{36}$

\section{The Effects of Dietary Vitamins and Minerals on Lung Function}

Numerous experimental and epidemiological studies have supported the importance of vitamins and antioxidants in the prevention of inflammatory diseases, including COPD. Data from the crosssectional MORGEN study, (the monitoring project on risk factors and health in the Netherlands) in a sample of 6555 adults in the Dutch population, showed that the intake of vitamin $C$ and beta-carotene, but not vitamin $E$, had a positive effect on lung function, but had no effect on respiratory symptoms. ${ }^{37}$ A prospective cohort study in the United Kingdom confirmed that a high dietary intake of vitamin $C$ or foods rich in this vitamin reduced the rate of lung function loss and thereby prevented development of COPD. ${ }^{38}$ Another 3-year study showed an improvement in lung function in a group of COPD patients consuming higher amounts of fruits and vegetables. ${ }^{39}$ In a similar manner, a study based on a random sample of adults from 3 European countries concluded that the intake of fruits, and particularly tomatoes, delayed declines in lung function. ${ }^{40}$ Tomatoes are very rich sources of lycopene, a carotenoid without vitamin A activity, ${ }^{41}$ which is believed to be responsible for the observed beneficial effects of tomatoes.

Broccoli is a vegetable having a high content of bioactive phytochemicals, such as glucosinolates, phenolic compounds, vitamin $\mathrm{C}$, and minerals. ${ }^{42}$ For example, extract of sulforaphane, a sulfur-rich compound found in broccoli, has been shown to increase nuclear factor erythroid-2-related factor 2 (Nrf2) and its regulated antioxidants in upper airways, and to improve the ability of macrophages to remove bacteria. ${ }^{43}$ Several studies reported that Nrf2 and its transcriptional activity decline with increasing COPD severity ${ }^{44-46}$ allowing for the hypothesis that sulforaphane may decrease oxidative stress and inflammation in COPD patients. To test this hypothesis, the randomized, placebo-controlled clinical trial of sulforaphane supplementation in patients with COPD for four weeks at doses of 25 and $150 \mu \mathrm{M}$ was initiated. Unfortunately, this therapy had no effect on the expression of Nrf2, and other antioxidants or markers of inflammation. ${ }^{47}$

Chalcones (1,2-diphenyl-2-propen-1-one) belonging to the flavonoid family, such as isoliquiritigenin (licorice roots) and xanthohumol (hops), have been shown to decrease pulmonary inflammation caused by lipopolysaccharide (LPS). ${ }^{48}$ However, no studies have been reported in COPD patients.

It is also important to mention, that the Beta-Carotene and Retinol Efficacy Trial (CARET) tested daily intake of the combination of $30 \mathrm{mg}$ beta-carotene and 25,000 IU vitamin A against placebo in 18,314 men and women. However, the CARET trial was terminated because of substantial evidence of harm; there were $28 \%$ more lung cancers and $17 \%$ more deaths in the active intervention group. ${ }^{49}$ On the other hand, a population-based cross-sectional study including 21,148 Korean adults showed that participants with the highest intake of vitamin $A$, beta-carotene, and vitamin $C$ had a significantly higher forced expiratory volume in 1 second $\left(\mathrm{FEV}_{1}\right)$ than those with the lowest intake. $^{50}$

A number of studies suggest that levels of specific microelements like selenium, manganese, and zinc are altered in patients with COPD. ${ }^{51-53}$ For example, some studies have shown that there is no effect of selenium on COPD, ${ }^{54}$ although other studies reported that selenium had therapeutic benefits. Indeed, COPD patients with acute upper respiratory tract infections receiving selenium with zinc, vitamin C, and Echinacea Purpurea showed less severe and shorter exacerbation episodes when compared with the placebo group. ${ }^{55}$ According to another study, intravenous administration of selenium with zinc 
and manganese significantly reduced the time COPD patients spent on mechanical ventilation. ${ }^{53}$ Likewise, a study based on data from 18,162 individuals has shown a direct relationship between serum levels of selenium and $\mathrm{FEV}_{1}$ in smokers. ${ }^{56}$

Taken together, the above-mentioned studies suggested that a high intake of fruits and vegetables rich in antioxidants is beneficial for the respiratory system and favorable for patients with COPD. However, future prospective randomized, controlled trials are needed to explore the role of natural bioactive compounds as well as their supplements on health status, lung function and risk of COPD development.

\section{Endogenous Antioxidants}

All cells contain antioxidant systems that specifically detoxify superoxide or hydrogen peroxide or contribute to the defense against ROS (Figure 2). Many antioxidant responses are controlled by the Nrf2, an evolutionary conserved transcription factor that is sequestered under basal conditions but upregulated acutely during oxidant attack. When activated, Nrf2 disassociates from its repressor protein KEAP 1 that reacts with oxidative radicals, translocates to the nucleus, binds to antioxidant response element and induces the transcription of defensive genes. As mentioned above, decreased Nrf2 expression and protein levels, and concomitantly, a lower activity of antioxidant defense, are found in tissues from COPD patients.

\section{Enzymatic Antioxidants}

Enzymatic antioxidants function by converting oxidized metabolic products in a multi-step process to hydrogen peroxide and then to water using cofactors such as iron, zinc, copper, and manganese. Hydrogen peroxide may also be converted to the potent oxidant hypochlorous acid in the presence of the chloride ion. This transformation is catalyzed by myeloperoxidase (Figure 2).

\section{Myeloperoxidase}

Myeloperoxidase (MPO) is an iron-containing enzyme with antimicrobial activity carried by neutrophil azurophilic granules. Among the antimicrobial agents, $\mathrm{MPO}$ is the most abundant and constitutes about $25 \%$ of the azurophilic granular proteins. ${ }^{6} \mathrm{MPO}$ uses peroxide as a substrate via peroxidation or chlorination reaction to produce hypochloric acid and other toxic substances that can kill different types of pathogens. Individuals deficient in MPO have an increased risk of infections and inflammatory diseases. ${ }^{57}$ Despite the beneficial anti-inflammatory effects of MPO, its excessive activity may cause protein nitrosylation, lipid peroxidation and tissue damage. ${ }^{58,59}$ In fact, levels of MPO in sputum and bronchoalveolar lavage are much greater in COPD patients than in controls. ${ }^{60,61}$ Moreover, MPO levels are elevated during exacerbations of COPD. ${ }^{62-64}$

The inhibition of MPO has been studied in a cigarette smoke-induced emphysema model, in guinea pigs. Animals treated with the MPO inhibitor showed protection against morphologic changes characteristic of emphysema. ${ }^{65}$ However, the potential consequences of chronic MPO inhibition in patients with COPD are unknown.

\section{Superoxide Dismutases}

Superoxide dismutases (SODs) are universal enzymes of aerobic organisms, which control the levels of reactive oxygen and nitrogen species by catalyzing the dismutation of superoxide to hydrogen peroxide and oxygen. Three isoforms of SOD exist: cytoplasmic Cu-ZnSOD (SOD1), mitochondrial MnSOD (SOD2), and extracellular $\mathrm{Cu}-Z n S O D 3$. The presence of specific SOD isoforms supports the importance of maintaining redox homeostasis between cellular compartments. The changes in SOD activity in a particular compartment may lead to the generation of a hydrogen peroxide concentration gradient and the subsequent activation of redox sensitive pathways. ${ }^{66}$

SOD 1 is constitutively expressed and it is abundant in bronchial and alveolar epithelial cells, fibroblasts, and capillary endothelial cells. ${ }^{67}$ In contrast to SOD 1, SOD2 is inducible by oxidative stress, hyperoxia, environmental pollutants such as cigarette smoke or ozone, and by inflammatory cytokines. Similar to SOD1, SOD2 expression is lower in lung tissue compared to other major organs; its expression is the highest in alveolar type II cells. ${ }^{68}$

Because SOD3 modulates O2.- levels in the vasculature, this $\mathrm{SOD}$ is linked to pathological conditions involving vascular dysfunctions. Polymorphisms in the SOD3 gene have been linked to type 2 diabetes, ischemic heart disease, acute lung injury and COPD. ${ }^{69}$ Through a direct binding property, SOD3 protects hyaluronic acid against oxidative fragmentation in models of asbestos- 


\section{Figure 2. Defense Mechanisms Against Free Radicals}

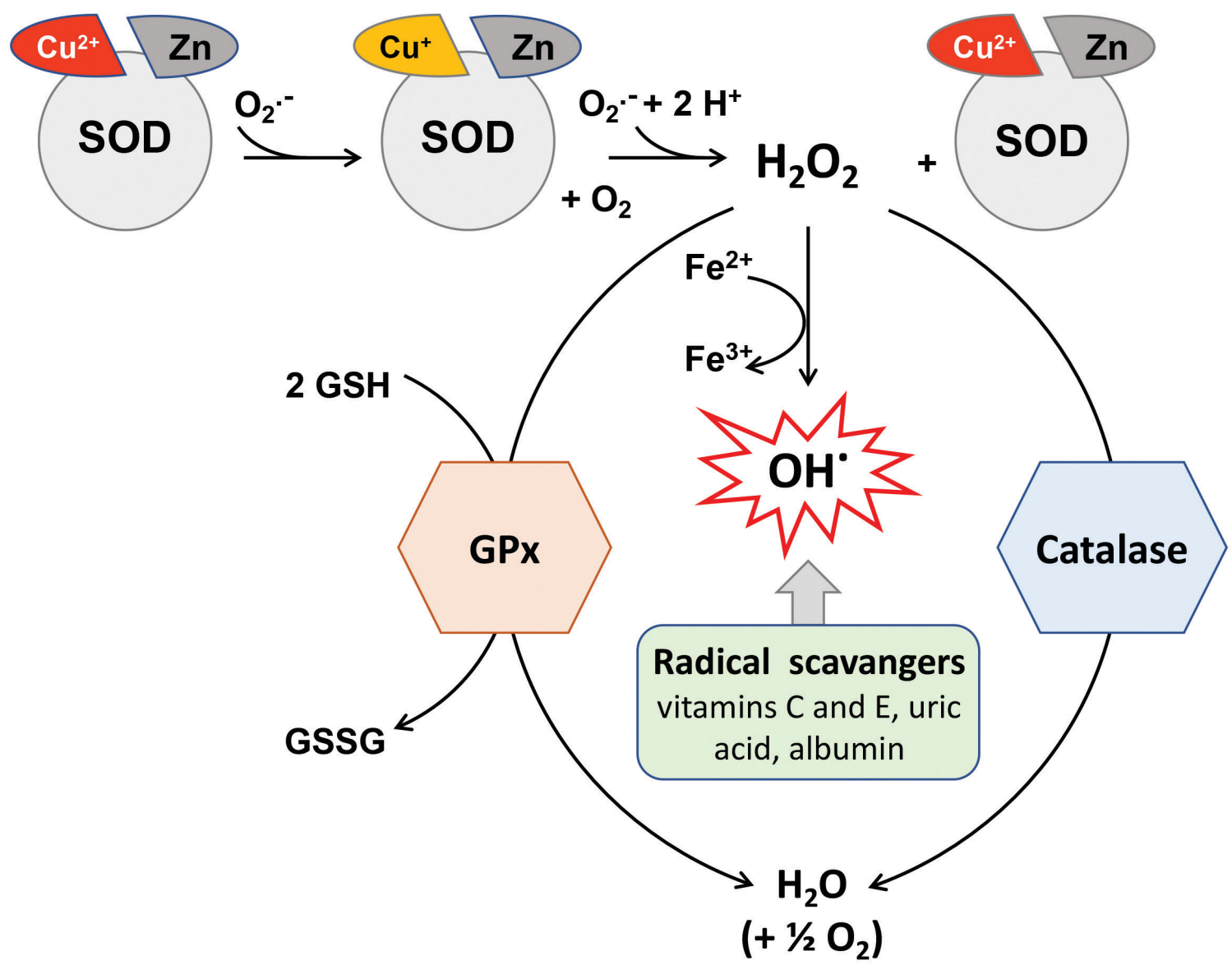

Catalytic removal of free radicals and reactive species by superoxide dismutase (SOD), catalase, glutathione peroxidase (GPx) and thiol-specific antioxidants. Myeloperoxidase (MPO) uses peroxide as a substrate via peroxidation or chlorination reaction to produce hypochloric acid (HOCl) and other toxic substances against different types of pathogens.

$\mathrm{SOD}=$ superoxide dismutase; $\mathrm{GPx}=$ glutathione peroxidase; $\mathrm{MPO}=$ myeloperoxidase; $\mathrm{HOCI}=$ hypochloric acid

induced lung injury and cigarette smoke-induced emphysema. ${ }^{70,71}$ Moreover, experimental data have shown that SOD3 modulates neutrophil recruitment and function. ${ }^{72}$

Superoxide dismutase is also known to help carry $\mathrm{NO}$ into hair follicles. While the NO relaxes the blood vessels and allows more blood to circulate to the hair follicles, SOD helps to remove the free radicals. This is beneficial for people who are experiencing premature hair loss. ${ }^{73}$

\section{Catalase}

Catalase is a heme moiety-containing enzyme located in peroxisomes and responsible for the conversion of hydrogen peroxide molecules to oxygen and water. It is an extremely efficient enzyme because one catalase molecule can convert millions of hydrogen peroxide molecules each second. ${ }^{74}$ Because of this property, catalase is used in facial mask treatments combining catalase with hydrogen peroxide with the intent of increasing cellular oxygenation in the upper layers of the facial epidermis. This treatment is expected to lower oxidative stress, DNA damage, malignant transformation, and to protect against age-associated skin oxidative damage. ${ }^{75}$

In the lungs, catalase is expressed during the later stages of development and becomes constitutively expressed in airway and alveolar epithelial cells. ${ }^{76} \mathrm{~A}$ decrease in catalase activity is observed in patients with asthma ${ }^{77}$ and in smokers with COPD. ${ }^{78}$ The 
overall biological role of catalase in pulmonary diseases remains unclear. For example, some studies suggest that inhibition of catalase might be a beneficial therapy for acute lung injury because this would preserve an effect of hydrogen peroxide on neutrophil phagocytic ability. ${ }^{79}$

\section{Glutathione Peroxidases}

The family of glutathione peroxidases (GPXs) consists of 8 isoforms, and 4 of these are expressed in the lung. The GPXs mediate the same reaction as catalase, namely, the recycling of hydrogen peroxide into water. However, these 2 enzymes have specific characteristics. As previously mentioned, catalase is an enzyme located in peroxisomes, and is activated when cellular peroxide concentrations exceed physiological levels. In contrast, the GPXs are involved in the physiological adjustment of peroxide concentrations in the intracellular and extracellular compartments, and are more versatile, so they can also act as scavengers and as repair enzymes. In addition, peroxide GPXs can also recycle peroxidized free polyunsaturated fatty acids and phospholipid hydroperoxides. ${ }^{80}$

It has been assumed that GPX1 is responsible for approximately 95\% of the overall GPX activity in lung tissue. ${ }^{81}$ GPX 1 deficient mice develop normally but are more susceptible to lung inflammation by influenza infection or cigarette smoke exposure. ${ }^{82,83}$ GPX1 is shown to promote proinflammatory cytokine production and neutrophilia in response to endotoxin, ${ }^{84}$ and to contribute to the development of ovalbumin-induced allergic asthma. 85

GPX2 is poorly expressed in healthy lungs, whereas GPX2 markedly increases in the airway epithelium in response to cigarette smoke exposure and inflammation. ${ }^{86,87}$ GPX3 was first identified in plasma and was found to be expressed by bronchial epithelial cells and alveolar macrophages. ${ }^{88,89}$ Different studies support a major role of GPX3 in extracellular antioxidant defense within the airway lumen. GPX4 is also known as phospholipid hydroperoxide and exists as cytosolic, mitochondrial, and nuclear isoforms. ${ }^{90}$ GPX 4 is primarily involved in oxidative lipid metabolism, ${ }^{91}$ although the role of GPX4 in lung pathophysiology remains unclear.

A study by Vibhuti et al reported reduced levels of glutathione and low activities of catalase and GXP in COPD patients. ${ }^{92}$ However, this observation remains to be replicated by other studies.

\section{Peroxiredoxins}

Peroxiredoxins (Prxs) comprise a family of 6 mammalian cysteine-dependent peroxidase enzymes that are major regulators of the cellular redox environment, and impact protein cysteine oxidation. Over the past years, Prxs have become recognized not only as oxidative stress defense enzymes but also as regulators of phospholipid homeostasis. ${ }^{93,94}$ Despite the knowledge that redox perturbations accompany pulmonary diseases like cancer, pulmonary fibrosis, and acute lung injury, little is known about the role of Prxs in the etiology of these diseases. ${ }^{95}$

\section{Endogenous Nonenzymatic Antioxidants}

The nonenzymatic antioxidants are characterized by their ability to intercept and terminate free radical chain reactions, and inactivate radicals and oxidants. ${ }^{96}$ The major endogenous nonenzymatic low-molecularmass antioxidants include N-acetylcysteine, glutathione, uric acid, melatonin, coenzyme $Q$ and others. Among contributors to the antioxidant defense system are also human blood proteins like albumin, ferritin, transferrin, haptoglobin and ceruloplasmin. For example, ceruloplasmin is a copper-containing ferroxidase that possesses ferroxidase and antioxidant activity, and inhibits iron-and copper-dependent lipid peroxidation and scavenging peroxide and superoxide anions. ${ }^{97}$ Moreover, ceruloplasmin is a physiologic inhibitor of $\mathrm{MPO},{ }^{98}$ a neutrophil enzyme that promotes oxidative stress in COPD. The antioxidant properties of serum albumin will be discussed in the following chapter.

\section{$\mathbf{N}$-acetylcysteine}

$\mathrm{N}$-acetylcysteine (NAC) possesses direct and indirect antioxidant properties. The free thiol group of NAC can directly interact with ROS to form NAC disulphide. ${ }^{99,100}$ However, as a glutathione precursor, NAC can exert an indirect antioxidant effect.

Both in vitro and in vivo studies have confirmed the protection of the alveolar epithelium from oxygen radical toxicity by treatment with $\mathrm{NAC} .{ }^{101}$ Data on the NAC effects in COPD suggest that NAC reduces elastase activity, ${ }^{99}$ hinders the loss of pulmonary glutathione, abolishes the effects of cigarette smoke, prevents thickening of the airway wall, and reduces the risk of exacerbations. ${ }^{102}$ The results of clinical 
trials support the usefulness of oral administration of NAC, generally $600 \mathrm{mg} /$ day, in chronic bronchitis and COPD patients to prevent exacerbations. ${ }^{103,104}$ Long-term therapy with NAC may reduce the risk of COPD exacerbation. ${ }^{105}$ Nevertheless, the available evidence is insufficient to recommend the routine use of NAC for the treatment of stable COPD patients. ${ }^{106}$ However, because of its antioxidant properties, NAC might be a potential add-on therapy in COPD patients.

\section{Glutathione}

Glutathione (GSH) is a low molecular weight thiol tripeptide ( $\gamma$-glutamyl-cysteinyl-glycine) abundant in almost all cellular compartments (in the nucleus, mitochondria, and cytoplasm). In humans, GSH is present in a high concentration $(1-10 \mathrm{mM})^{107}$ and it is involved in cell differentiation, senescence and death, detoxification of xenobiotics, regulation of enzymatic activity, and synthesis of proteins and nucleotides. ${ }^{108}$ As an antioxidant, GSH reduces ROS during the enzymatic and nonenzymatic reactions. It regenerates other oxidized antioxidants like vitamin $C$ and vitamin $\mathrm{E}$, is involved in the repair of peroxidized lipids and in the maintenance of sulfhydryl moieties of proteins in the reduced form. GSH functions in conjunction with $3 e$ groups of enzymes glutathione peroxidase, glutathione reductase, and glutathione oxidase.

GSH homeostasis is regulated by its de novo synthesis but also by recycling and cellular export. The rate-limiting step in the de novo synthesis of the GSH is catalyzed by gamma-glutamyl-cysteine synthetase (also known as glutamine-cysteine ligase), which is a target gene of $\mathrm{Nrf} 2{ }^{109}$ The Nrf2 coordinates the basal and stress-inducible activation of the glutamate-cysteine ligase complex ${ }^{110}$ and regulates the transcription of glutathione peroxidase 2 and glutathione S-transferases. ${ }^{111}$

The antioxidant function of GSH is accomplished mainly by GSH peroxidase reactions, which reduce hydrogen peroxide and lipid peroxide. ${ }^{112}$ When $\mathrm{GSH}$ is oxidized, it forms GSH disulphide, which can be reduced again to GSH with the help of glutathione reductases, another Nrf2 targets, in an NADPH-dependent manner. ${ }^{113}$ Thus, through the coordinated activation of GSH production, utilization, and regeneration, Nrf2 ensures maintenance of the intracellular levels of reduced GSH. ${ }^{114}$

The key role of GSH as an antioxidant is demonstrated by the experimental depletion of GSH using buthionine sulfoximine, an inhibitor of GSH synthesis. This depletion of GSH results in a worsening effect in many disease models. Conversely, recovering GSH levels with precursors of its synthesis, such as $\mathrm{N}$-acetyl-cysteine or 2-oxothiazolidine-4-carboxylic acid, increase the protective effects. ${ }^{115}$

Glutathione deficiency is associated with chronic bronchitis, COPD, cystic fibrosis, idiopathic pulmonary fibrosis, bacterial and viral infections, and toxicity of various foreign compounds (smoke, pollutants, and drugs). ${ }^{116}$ However, clinical studies using GSH as a therapeutic agent have shown mixed results. In the older study, when GSH (600 mg twice daily for 3 days) was given by aerosol to 10 patients with idiopathic pulmonary fibrosis, a rise in epithelial lining fluid GSH and reduced superoxide release from macrophages was detected. ${ }^{117}$ Noticeably, GSH inhalation is not recommended for lung cancer patients because GSH may reduce cytotoxicity to chemotherapeutic compounds and repair drug-induced injury at the DNA level. For example, GSH was found to detoxify or inactivate platinum drugs, commonly used for the treatment of advanced stage lung cancer patients ${ }^{116}$ Moreover, in a trial of 8 asthmatic patients who received nebulized GSH (600 $\mathrm{mg}$ with $4 \mathrm{ml}$ of $0.9 \%$ sodium chloride) one week apart, adverse effects, such as bronchoconstriction, have occurred. Researchers assumed that this was probably due to the sulphite formation in the nebulized solution and/or the metabolism of GSH into leukotrienes, potent proinflammatory bronchoconstrictors. ${ }^{118}$ Taken together, GSH treatment might be capable of providing antioxidant protection to both the upper and lower respiratory airways however, additional research studies are necessary. So far, GSH is not recommended as a potential treatment for COPD and emphysema patients. $^{119}$

\section{Coenzyme Q10}

Coenzyme $\mathrm{Q}$ (Co $\mathrm{Q}$ ) is a benzoquinone derivative localized in the mitochondrial respiratory chain as well as in other internal membranes. The CoQ provides antioxidant protection to cell membranes and plasma lipoproteins. ${ }^{120}$

A significant reduction in the rate of CoQ biosynthesis occurs during aging and age-associated diseases. ${ }^{121-124}$ In patients with COPD, dietary supplementation with CoQ10 seems to improve functional performance and dyspnea. ${ }^{125}$ 
A recent meta-analysis summarized the efficacy of CoQ10 in patients with pathologies, in which inflammation is a common factor, like cardiocerebral vascular disease, multiple sclerosis, obesity, renal failure, rheumatoid arthritis, diabetes, and fatty liver disease. ${ }^{126}$ Administration of CoQ10 in doses ranging from $60 \mathrm{mg}-500 \mathrm{mg} /$ day significantly decreased production of inflammatory markers. ${ }^{126}$ Nevertheless, further experimental studies and clinical trials involving a greater number of participants are needed to definitively assess the benefits of CoQ10 treatment. $^{127}$

\section{Uric Acid}

Uric acid (UA) is an intermediate product of the purine degradation pathway and provides approximately $60 \%$ of free radical scavenging capacity in plasma. ${ }^{128}$ Although the antioxidant effect of UA might have therapeutic benefits, high plasma concentrations of UA have been associated with obesity, insulin resistance, and hyperuricemia. ${ }^{129,130}$ It is possible that increases in circulating levels of UA reflect a protective response against oxidative stress that is linked to obesityassociated metabolic syndrome. Several studies have indicated a role of UA in exacerbations and lung function, and in the physical capacity of patients with COPD. ${ }^{131,132}$

\section{Melatonin}

Melatonin (N-acetyl-5-methoxytryptamine) is an endogenous hormone derived from tryptophan that is mainly released from the pineal gland in the dark. Melatonin expresses anti-inflammatory and antioxidant properties, and regulates different biological functions such as sleep, circadian rhythm, immunity, reproduction and blood pressure control. ${ }^{133}$ Melatonin protects lipids, proteins, and nuclear DNA from oxidative damage. ${ }^{134}$

Melatonin is not only endogenously generated but it is also widely available in fruits and vegetables. Numerous in vivo studies testing high doses of melatonin reported extremely low toxicities. ${ }^{135}$ Torres et al found that melatonin decreases the levels of oxidative stress markers and increased both enzymatic and nonenzymatic antioxidant capacities in the lung. ${ }^{136}$ Melatonin is also used to treat sleep disturbances and insomnias caused by aging, as well as pathological conditions including COPD. ${ }^{137}$

\section{Blood Proteins as Antioxidants}

Human blood proteins are vulnerable to oxidative damage because free radicals can cause alterations in the electrical charge of proteins, induce crosslinking of proteins, and increase their susceptibility to proteolysis. ${ }^{138}$ Proteins that have metals at their active sites are sensitive to metal catalyzed oxidation. ${ }^{139}$ Oxidation can generate protein hydroperoxides, which generate additional radicals upon interactions with metal ions. Some oxidized proteins become functionally inactive and are rapidly removed; others can gain novel biological activities and thereby contribute to the various pathophysiological processes. ${ }^{140}$

Specific blood proteins like albumin, ceruloplasmin, metallothionein, ferritin, myoglobin, transferrin, alpha-1-acid glycoprotein, and haptoglobin, may act as antioxidants. It has been proposed that proteins account for more than half of the antioxidant capacity in blood. ${ }^{141}$

\section{Human Serum Albumin}

Human serum albumin (HSA) is the main extracellular protein maintaining the plasma redox state. ${ }^{142}$ The sulphur-containing residues, methionine and cysteine, account for $40 \%-80 \%$ of the total antioxidant activity of HSA. ${ }^{143}$

Albumin is well known for its binding of various molecules; therefore, antioxidant activity may result from its ability to bind bilirubin, homocysteine, and lipids. For example, the binding of HSA to polyunsaturated fatty acids and sterols may prevent lipid peroxidation. ${ }^{144}$

Based on estimates, under physiological conditions, one-third of the HSA exists as disulfides mixed with cysteine, homocysteine, or glutathione (HSA-S-S-R), whereas the rest of the HSA is in a reduced form with a free thiol in the Cys-34 residue (HSA-SH). ${ }^{145}$ Under oxidative stress, Cys34 thiol shifts to a sulfenic acid (HSA-SOH), which can be irreversibly oxidized to the sulfinic (HSA-SO2H) and sulfonic (HSA-SO3H) acids or, through the reactions with glutathione, can be returned to the HSA-SH reduced form. ${ }^{146}$ Thus, an outcome of the oxidative process may depend on whether the sulfenic acid is further oxidized, or whether it is reduced, leading to the initial HSA-SH (Figure 3).

During pathological conditions like diabetes, COPD, 
and kidney disease, structural modifications of HSA induced by glucose or acrolein can strongly impair its antioxidant properties. ${ }^{147}$

\section{Alpha-1 Antitrypsin}

Alpha-1 antitrypsin (AAT) is viewed as a key inhibitor of serine proteases, specifically, neutrophil elastase and proteinase 3. However, numerous studies have shown that, aside from its anti-protease properties, AAT has anti-inflammatory and immune regulatory functions, and some of these functions seem to be independent of the anti-protease activities.

Similar to albumin, AAT has exposed methionine (Met) residues and a free cysteine at the position 232, which can be attacked by oxidants. ${ }^{148,149}$ The Met-358 is at the "P1 position," which is located in the reactive site, and determines anti-protease activity of AAT. Therefore, oxidative change of this Met into methionine sulfoxide inactivates AAT as a serine protease inhibitor. ${ }^{150}$ Carp et al reported that AAT isolated from bronchoalveolar lavage fluid of smokers contains 4 oxidized Met residues with loss of $40 \%$ of anti-protease activity. ${ }^{151}$ Other investigators suggested that inactivation of AAT by oxidation of either Met-351 or Met-358 provides a mechanism for regulation of its activity at sites of inflammation. ${ }^{152}$
Experimental findings have suggested that the oxidation of Met residues by cigarette smoke or free radicals released from inflammatory cells not only reduces the anti-elastase activity of AAT but also converts AAT into a proinflammatory molecule. Likewise, oxidized AAT has been found to induce monocyte chemoattractant protein-1 (MCP-1) release from monocytes. ${ }^{153} \mathrm{MCP}-1$ belongs to the CC chemokine family and functions as a chemoattractant for mononuclear phagocytes, T lymphocytes, B cells, and natural killer cells. Increased MCP-1 and its receptor, CCR2, in the lung have been positively associated with leukocyte infiltration in COPD. ${ }^{154}$

The oxidized form of AAT has also been found to express anti-inflammatory effects. For instance, oxidized AAT inhibits inflammation in response to cigarette smoke in vivo ${ }^{155}$ and induces a broad anti-inflammatory profile in gene expression of primary human lung microvascular endothelial cells. ${ }^{156}$ Moreover, oxidized AAT was found to prevent acute liver injury in vivo. ${ }^{157}$ We recently provided in vitro evidence that both native and oxidized AAT control equally well ATP-induced IL$1 \beta$ release from human mononuclear blood cells. ${ }^{158}$

Available findings have allowed us to speculate that the biological activities of oxidized AAT may depend on the magnitude of AAT oxidation, in a

\section{Figure 3. Schematic Presentation of Antioxidant Activity of Human Albumin and Putative Role of Alpha-1 Antitrypsin}

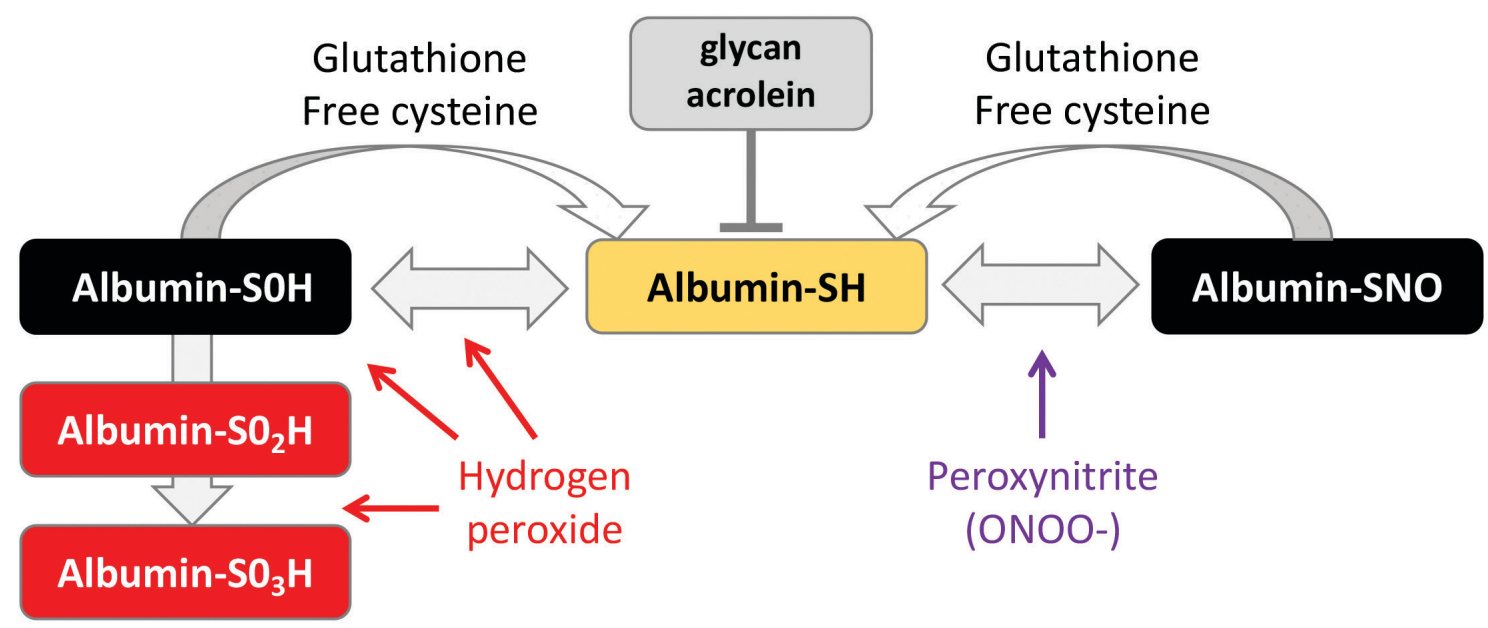

Oxidative stress 
manner similar to that discussed for HSA (Figure 3). Similar to albumin, AAT can function as an indirect free radical scavenger by interacting with neutrophil alpha defensins, ${ }^{159-161}$ free fatty acids, ${ }^{162}$ and free heme. ${ }^{163}$ As an example, Tiriveedhi et al reported that lung transplant patients, who developed chronic lung allograft rejection, show increased defensin and decreased serum AAT levels along with high concentrations of AATdefensin complexes in their bronchial lavage. ${ }^{164}$

Some studies have proposed that a fraction of the AAT protein is S-nitrosylated under physiological conditions, and that AAT nitrosylation is more efficient than the nitrosylation of bovine serum albumin or glutathione. ${ }^{165}$ The S-NO-AAT expresses a potent antimicrobial activity, inhibits cysteine proteases, and induces heme oxygenase-1 expression in hepatic ischemia-reperfusion injury in rats. ${ }^{166}$ A recent study reported that S-nitrosylation altered AAT to a proinflammatory protein, which facilitated the inflammatory state of macrophages by upregulating proinflammatory molecules and the activation of MAPK signalling pathways. ${ }^{167}$

However, the antioxidant properties of AAT remain largely unknown. Further investigations are required to understand fully the dynamics of AAT oxidation, and the mechanism of action of oxidized AAT.

\section{Oxidants/Antioxidants in the Liver and Lung of Individuals with Inherited Alpha-1 Antitrypsin Deficiency}

Severe inherited alpha-1 antitrypsin deficiency (AATD) is a monogenic, autosomal, co-dominant, inherited disease associated with a risk for developing liver disease at any age and/or early onset emphysema. The most clinically relevant $Z$ variant of AAT protein differs from the normal $M$ by a single amino acid substitution (Glu342Lys). This mutation results in protein accumulation within the endoplasmic reticulum (ER) of hepatocytes and other AAT-producing cells, which leads to ER stress or an aberrant inflammatory response. ${ }^{168}$ Studies in experimental models have shown an association between AATD and oxidative stress. ${ }^{169}$ It has been demonstrated that the expression of human Z AAT protein in mouse liver leads to elevated oxidative stress and lowered antioxidant protection. ${ }^{170}$ However, selenoprotein $S$ was found to reduce ER stress and enhance cell ability to cope with the burden of misfolded Z AAT protein. ${ }^{171,172}$

Liver is a major organ attacked by ROS. ${ }^{173}$ The oxidative stress is regarded as one of the pathological mechanisms during initiation and progression of liver fibrosis/cirrhosis, alcoholic liver diseases, and non-alcoholic steatohepatitis. Concomitantly, systemic oxidative stress arising during liver damage can affect extrahepatic organs. ${ }^{174}$

AATD-related liver diseases have a highly variable clinical phenotype, suggesting that disease progression is strongly influenced by environmental and genetic modifiers. ${ }^{172}$ Genes involved in pathways related to oxidative stress and antioxidant defense might therefore be potential genetic modifiers in AATDrelated liver diseases, and warrant further investigation.

Numerous studies have shown an increase of systemic oxidative stress markers in the lungs of cigarettes smokers and COPD patients without and with inherited AATD. ${ }^{175-181}$

The finding that the administration of alltrans retinoic acid (ATRA) in elastase-induced emphysema in rats reversed the emphysematous changes, ${ }^{182}$ suggested that ATRA might be a beneficial therapy for patients with emphysema. However, clinical trials of emphysema patients with and without AATD have failed to demonstrate measurable improvements in lung destruction. ${ }^{183}$

Another approach has been based on the observation that emphysema patients showed a marked reduction in the levels of hyaluronic acid, ${ }^{184}$ and that therapy with hyaluronic acid protected elastase-induced emphysema in mice. ${ }^{185}$ Hyaluronic acid is a high molecular weight glycosaminoglycan involved in the regulation of migration of inflammatory cells and the scavenging of free radicals. ${ }^{186}$ The mechanism by which hyaluronic acid may protect elastin is not yet understood. One possibility is that hyaluronic acid binds to elastic fibres and prevents them from attack by elastase. ${ }^{187}$ Investigators have therefore hypothesized that aerosols of hyaluronic acid inhaled daily may protect against lung elastic fiber injury. To test this hypothesis, trials of inhaled hyaluronic acid in individuals with AATD are under way in the hope of preventing the progression of this lung disease.

Remarkably, a study by Escribano et al revealed that, when compared with the control group, children with severe AATD showed significantly increased 
levels of oxidative stress biomarkers and decreased levels of antioxidants, as expressed by lower total and reduced glutathione levels, decreased catalase activity, and increased glutathione peroxidase activity. ${ }^{188}$ These findings supported oxidative stress as a feature of AATD contributing to the risk of disease development late in life. Moreover, oxidation of AAT may lead to a loss of its antiprotease activity that is already lower in AATD, so the antioxidant potential in the treatment of emphysema patients with AATD needs to be considered. ${ }^{189}$

Until now there has been limited knowledge about the antioxidant status in AATD individuals, so the usefulness of antioxidant therapies remains to be investigated.

\section{Conclusion}

ROS are the natural consequence of aerobic metabolism and are important for basic cellular functions, including proliferation, inflammation, apoptosis, and gene expression. However, if the level of radicals exceeds that which the body can handle, then oxidative stress occurs. Factors increasing the production of reactive species can be internal, such as inflammation, or external such as pollution, UV exposure, xenobiotic compounds, and cigarette smoke. Many substances associated with oxidative stress increase during aging and in patients with chronic inflammatory diseases, like COPD. To protect the cells and organ systems against ROS, humans have evolved a highly sophisticated and complex internal and external antioxidant protection system. Preclinical studies and clinical trials suggest that antioxidants, such as small thiol molecules ( $\mathrm{N}$-acetyl-L-cysteine and carbocysteine), antioxidant enzymes (glutathione peroxidases), activators of Nrf2-regulated antioxidant defense system (sulforaphane), and vitamins, for example, C, E, and D, enhance the endogenous antioxidant system and reduce oxidative stress. Among important antioxidants are blood proteins, specifically albumin. Whether AAT is a significant contributor to the antioxidant protein pool in human blood remains to be investigated in more detail. Further basic and translational research is needed to identify individuals more susceptible to ROS damage, and to clarify whether ROS is an important target to treat COPD and AATD patients. This knowledge might be critically important for identifying patients who benefit most from the therapy with purified AAT protein and/or specific drugs with antioxidant potentials.

\section{Acknowledgements}

The author thanks Dr. S. Wrenger for help with figure preparation.

\section{Declaration of Interest}

SJ has no conflicts of interest to declare. 


\section{References}

1. Elbatreek MH, Pachado MP, Cuadrado A, Jandeleit-Dahm K, Schmidt H. Reactive oxygen comes of age: mechanism-based therapy of diabetic end-organ damage. Trends Endocrinol Metab. 2019;30(5):312-327.

doi: https://doi.org/10.1016/j.tem.2019.02.006

2. Di Meo S, Reed TT, Venditti P, Victor VM. Role of ROS and RNS sources in physiological and pathological conditions. Oxid Med Cell Longev. 2016;1245049.

doi: https://doi.org/10.1155/2016/1245049

3. Fritz R, Bol J, Hebling U, et al. Compartment-dependent management of $\mathrm{H}(2) \mathrm{O}(2)$ by peroxisomes. Free Radic Biol Med. 2007;42(7):1119-1129.

doi: https://doi.org/10.1016/j.freeradbiomed.2007.01.014

4. Hall S, McDermott C, Anoopkumar-Dukie S, et al. Cellular effects of pyocyanin, a secreted virulence factor of pseudomonas aeruginosa. Toxins (Basel). 2016;8(8).

doi: https://doi.org/10.3390/toxins 8080236

5. Yang Y, Bazhin AV, Werner J, Karakhanova S. Reactive oxygen species in the immune system. Int Rev Immunol. 2013;32(3):249270. doi: https://doi.org/10.3109/08830185.2012.755176

6. Segal AW. How neutrophils kill microbes. Annu Rev Immunol. 2005;23:197-223.

doi:https://doi.org/10.1146/annurev.immunol.23.021704.115653

7. Shadyro O, Samovich S, Edimecheva I. Free-radical and biochemical reactions involving polar part of glycerophospholipids. Free Radic Biol Med. 2019;144:6-15. doi: https://doi.org/10.1016/j.freeradbiomed.2019.02.033

8. Ahsan H, Ali A, Ali R. Oxygen free radicals and systemic autoimmunity. Clin Exp Immunol. 2003;131(3):398-404.

doi: https://doi.org/10.1046/j.1365-2249.2003.02104.x

9. Pantopoulos K, Weiss G, Hentze MW. Nitric oxide and the posttranscriptional control of cellular iron traffic. Trends Cell Biol. 1994;4(3):82-86.

doi: https://doi.org/10.1016/0962-8924(94)90179-1

10. Atkinson RW, Butland BK, Anderson HR, Maynard RL. Longterm concentrations of nitrogen dioxide and mortality: a metaanalysis of cohort studies. Epidemiology. 2018;29(4):460-472. doi: https://doi.org/10.1097/EDE.0000000000000847

11. Drew B, Leeuwenburgh C. Aging and the role of reactive nitrogen species. Ann N Y Acad Sci. 2002;959(1):66-81. doi: https://doi.org/10.1111/j.1749-6632.2002.tb02084.x

12. Pryor WA, Stone K. Oxidants in cigarette smoke. Radicals, hydrogen peroxide, peroxynitrate, and peroxynitrite. Ann NY Acad Sci. 1993;686(1):12-27.

doi: https://doi.org/10.1111/j.1749-6632.1993.tb39148.x
13. Lin JL, Thomas PS. Current perspectives of oxidative stress and its measurement in chronic obstructive pulmonary disease. COPD. 2010;7(4):291-306. doi: https://doi.org/10.3109/15412555.2010.496818

14. Rahman I, Adcock IM. Oxidative stress and redox regulation of lung inflammation in COPD. Eur Respir J. 2006;28(1):219-242. doi: https://doi.org/10.1183/09031936.06.00053805

15. Repine JE, Bast A, Lankhorst I. Oxidative stress in chronic obstructive pulmonary disease. Oxidative Stress Study Group. Am J Respir Crit Care Med. 1997;156(2 Pt 1):341-357. doi: https://doi.org/10.1164/ajrccm.156.2.9611013

16. Marginean C, Popescu MS, Vladaia M, Tudorascu D, Pirvu DC, Petrescu F. Involvement of oxidative stress in COPD. Curr Health Sci J. 2018;44(1):48-55. doi: https://doi.org/10.12865/CHSJ.44.01.08

17. McGuinness AJ, Sapey E. Oxidative stress in COPD: sources, markers, and potential mechanisms. J Clin Med. 2017;6(2). doi: https://doi.org/10.3390/jcm6020021

18. Wiegman CH, Michaeloudes C, Haji G, et al. Oxidative stressinduced mitochondrial dysfunction drives inflammation and airway smooth muscle remodeling in patients with chronic obstructive pulmonary disease. $J$ Allergy Clin Immunol. 2015;136(3):769-780.

doi: https://doi.org/10.1016/j.jaci.2015.01.046

19. Belchamber KBR, Singh R, Wedzicha JA, Barnes PJ, Donnelly LE. Elevated mitochondrial reactive oxygen species in COPD macrophages at exacerbation and with bacterial phagocytosis. Eur Respir J. 2015;46(59).

doi: https://doi.org/10.1183/13993003.congress-2015.PA387

20. Hoffmann RF, Zarrintan S, Brandenburg SM, et al. Prolonged cigarette smoke exposure alters mitochondrial structure and function in airway epithelial cells. Respir Res. 2013;14:97. doi: https://doi.org/10.1186/1465-9921-14-97

21. Loukides S, Bakakos P, Kostikas K. Oxidative stress in patients with COPD. Curr Drug Targets. 2011;12(4):469-477. doi: https://doi.org/10.2174/138945011794751573

22. Neeraj, Pramod J, Singh S, Singh J. Antioxidants to the rescue of cell under invasion of free radicals-a review. Int J Basic Appl Med Sci. 2013;3:190-200. doi: http://www.cibtech.org/jms.htm

23. Liguori I, Russo G, Curcio F, et al. Oxidative stress, aging, and diseases. Clin Interv Aging. 2018;13:757-772. doi: https://doi.org/10.2147/CIA.S158513

24. De la Fuente M, Miquel J. An update of the oxidationinflammation theory of aging: the involvement of the immune system in oxi-inflamm-aging. Curr Pharm Des. 2009;15(26):30033026. doi: https://doi.org/10.2174/138161209789058110 
25. Manach C, Morand C, Crespy V, et al. Quercetin is recovered in human plasma as conjugated derivatives which retain antioxidant properties. FEBS Lett. 1998;426(3):331-336. doi: https://doi.org/10.1016/S0014-5793(98)00367-6

26. Upston JM, Witting PK, Brown AJ, Stocker R, Keaney JF, Jr. Effect of vitamin $E$ on aortic lipid oxidation and intimal proliferation after arterial injury in cholesterol-fed rabbits. Free Radic Biol Med. 2001;31(10):1245-1253.

doi: https://doi.org/10.1016/S0891-5849(01)00721-3

27. Northrop-Clewes CA, Thurnham DI. Monitoring micronutrients in cigarette smokers. Clin Chim Acta. 2007;377(1-2):14-38. doi: https://doi.org/10.1016/j.cca.2006.08.028

28. Beatty S, Koh H, Phil M, Henson D, Boulton M. The role of oxidative stress in the pathogenesis of age-related macular degeneration. Surv Ophthalmol. 2000;45(2):115-134. doi: https://doi.org/10.1016/S0039-6257(00)00140-5

29. Sies H, Stahl W, Sundquist AR. Antioxidant functions of vitamins. Vitamins E and C, beta-carotene, and other carotenoids. Ann NY Acad Sci. 1992;669(1):7-20.

doi: https://doi.org/10.1111/j.1749-6632.1992.tb17085.x

30. Koike K, Ishigami A, Sato Y, et al. Vitamin C prevents cigarette smoke-induced pulmonary emphysema in mice and provides pulmonary restoration. Am J Respir Cell Mol Biol. 2014;50(2):347357. doi: https://doi.org/10.1165/rcmb.2013-0121OC

31. Gonzalez de Vega R, Fernandez-Sanchez ML, Fernandez JC, Alvarez Menendez FV, Sanz-Medel A. Selenium levels and glutathione peroxidase activity in the plasma of patients with type II diabetes mellitus. J Trace Elem Med Biol. 2016;37:44-49. doi: https://doi.org/10.1016/j.jtemb.2016.06.007

32. Alehagen U, Johansson P, Bjornstedt M, Rosen A, Post C, Aaseth J. Relatively high mortality risk in elderly Swedish subjects with low selenium status. Eur J Clin Nutr. 2016;70(1):91-96. doi: https://doi.org/10.1038/ejcn.2015.92

33. Chasapis CT, Loutsidou AC, Spiliopoulou CA, Stefanidou ME. Zinc and human health: an update. Arch Toxicol. 2012;86(4):521534. doi: https://doi.org/10.1007/s00204-011-0775-1

34. Li L, Yang X. The essential element manganese, oxidative stress, and metabolic diseases: links and interactions. Oxid Med Cell Longev. 2018;7580707.

doi: https://doi.org/10.1155/2018/7580707

35. Aguirre JD, Culotta VC. Battles with iron: manganese in oxidative stress protection. J Biol Chem. 2012;287(17):1354113548. doi: https://doi.org/10.1074/jbc.R111.312181

36. Kehl-Fie TE, Skaar EP. Nutritional immunity beyond iron: a role for manganese and zinc. Curr Opin Chem Biol. 2010;14(2):218224. doi: https://doi.org/10.1016/j.cbpa.2009.11.008
37. Grievink L, Smit HA, Ocke MC, van 't Veer P, Kromhout D. Dietary intake of antioxidant (pro)-vitamins, respiratory symptoms and pulmonary function: the MORGEN study. Thorax. 1998;53(3):166-171.

doi: https://doi.org/10.1136/thx.53.3.166

38. McKeever TM, Scrivener S, Broadfield E, Jones Z, Britton J, Lewis SA. Prospective study of diet and decline in lung function in a general population. Am J Respir Crit Care Med. 2002;165(9):12991303. doi: https://doi.org/10.1164/rccm.2109030

39. Keranis E, Makris D, Rodopoulou P, et al. Impact of dietary shift to higher-antioxidant foods in COPD: a randomised trial. Eur Respir J. 2010;36(4):774-780.

doi: https://doi.org/10.1183/09031936.00113809

40. Garcia-Larsen V, Potts JF, Omenaas E, et al. Dietary antioxidants and 10-year lung function decline in adults from the ECRHS survey. Eur Respir J. 2017;50(6).

doi: https://doi.org/10.1183/13993003.02286-2016

41. Agarwal S, Rao AV. Tomato lycopene and its role in human health and chronic diseases. CMAJ. 2000;163(6):739-744.

42. Ares AM, Nozal MJ, Bernal J. Extraction, chemical characterization and biological activity determination of broccoli health promoting compounds. $J$ Chromatogr $A$. 2013;1313:78-95.

doi: https://doi.org/10.1016/j.chroma.2013.07.051

43. Riedl MA, Saxon A, Diaz-Sanchez D. Oral sulforaphane increases Phase II antioxidant enzymes in the human upper airway. Clin Immunol. 2009;130(3):244-251.

doi: https://doi.org/10.1016/j.clim.2008.10.007

44. Goven D, Boutten A, Lecon-Malas V, et al. Altered Nrf2/ Keap1-Bach1 equilibrium in pulmonary emphysema. Thorax. 2008;63(10):916-924.

doi: https://doi.org/10.1136/thx.2007.091181

45. Suzuki M, Betsuyaku T, Ito Y, et al. Down-regulated NF-E2related factor 2 in pulmonary macrophages of aged smokers and patients with chronic obstructive pulmonary disease. Am J Respir Cell Mol Biol. 2008;39(6):673-682. doi: https://doi.org/10.1165/rcmb.2007-0424OC

46. Harvey CJ, Thimmulappa RK, Sethi S, et al. Targeting Nrf2 signaling improves bacterial clearance by alveolar macrophages in patients with COPD and in a mouse model. Sci Transl Med. 2011;3(78):78ra32.

doi: https://doi.org/10.1126/scitranslmed.3002042

47. Wise RA, Holbrook JT, Criner G, et al. Lack of effect of oral sulforaphane administration on nrf2 expression in COPD: a randomized, double-blind, placebo-controlled trial. PLoS One. 2016;11(11):e0163716.

doi: https://doi.org/10.1371/journal.pone.0163716 
48. Lv H, Liu Q, Wen Z, Feng H, Deng X, Ci X. Xanthohumol ameliorates lipopolysaccharide (LPS)-induced acute lung injury via induction of AMPK/GSK3beta-Nrf2 signal axis. Redox Biol. 2017;12:311-324. doi: https://doi.org/10.1016/j.redox.2017.03.001

49. Omenn GS, Goodman GE, Thornquist MD, et al. Risk factors for lung cancer and for intervention effects in CARET, the Beta-Carotene and Retinol Efficacy Trial. J Natl Cancer Inst. 1996;88(21):1550-1559.

doi: https://doi.org/10.1093/jnci/88.21.1550

50. Hong JY, Lee CY, Lee MG, Kim YS. Effects of dietary antioxidant vitamins on lung functions according to gender and smoking status in Korea: a population-based cross-sectional study. BMJ Open. 2018;8(4):e020656.

doi: https://doi.org/10.1136/bmjopen-2017-020656

51. Berger MM. Can oxidative damage be treated nutritionally? Clin Nutr. 2005;24(2):172-183.

doi: https://doi.org/10.1016/j.clnu.2004.10.003

52. Berthon BS, Wood LG. Nutrition and respiratory health-feature review. Nutrients. 2015;7(3):1618-1643.

doi: https://doi.org/10.3390/nu7031618

53. El-Attar M, Said M,El-Assal G, Sabry NA, Omar E, Ashour L. Serum trace element levels in COPD patient: the relation between trace element supplementation and period of mechanical ventilation in a randomized controlled trial. Respirology. 2009;14(8):11801187. doi: https://doi.org/10.1111/j.1440-1843.2009.01622.x

54. Hirayama F, Lee AH, Oura A, Mori M, Hiramatsu N, Taniguchi $\mathrm{H}$. Dietary intake of six minerals in relation to the risk of chronic obstructive pulmonary disease. Asia Pac J Clin Nutr. 2010;19(4):572-577.

55. Isbaniah F, Wiyono WH, Yunus F, Setiawati A, Totzke U, Verbruggen MA. Echinacea purpurea along with zinc, selenium and vitamin $C$ to alleviate exacerbations of chronic obstructive pulmonary disease: results from a randomized controlled trial. $J$ Clin Pharm Ther. 2011;36(5):568-576.

doi: https://doi.org/10.1111/j.1365-2710.2010.01212.x

56. $\mathrm{Hu}$ G, Cassano PA. Antioxidant nutrients and pulmonary function: the Third National Health and Nutrition Examination Survey (NHANES III). Am J Epidemiol. 2000;151(10):975-981. doi: https://doi.org/10.1093/oxfordjournals.aje.a010141

57. Kutter D, Devaquet P, Vanderstocken G, Paulus JM, Marchal V, Gothot A. Consequences of total and subtotal myeloperoxidase deficiency: risk or benefit ? Acta Haematol. 2000;104(1):10-15. doi: https://doi.org/10.1159/000041062

58. Khan AA, Alsahli MA, Rahmani AH. Myeloperoxidase as an active disease biomarker: recent biochemical and pathological perspectives. Med Sci (Basel). 2018;6(2). doi: https://doi.org/10.3390/medsci6020033
59. Naegelen I, Beaume N, Plancon S, Schenten V, Tschirhart EJ, Brechard S. Regulation of neutrophil degranulation and cytokine secretion: a novel model approach based on linear fitting. J Immunol Res. 2015;2015:817038. doi: https://doi.org/10.1155/2015/817038

60. Keatings VM, Barnes PJ. Granulocyte activation markers in induced sputum: comparison between chronic obstructive pulmonary disease, asthma, and normal subjects. Am J Respir Crit Care Med. 1997;155(2):449-453.

doi: https://doi.org/10.1164/ajrccm.155.2.9032177

61. Pesci A, Balbi B, Majori M, et al. Inflammatory cells and mediators in bronchial lavage of patients with chronic obstructive pulmonary disease. Eur Respir J. 1998;12(2):380-386. doi: https://doi.org/10.1183/09031936.98.12020380

62. Fiorini G, Crespi S, Rinaldi M, Oberti E, Vigorelli R, Palmieri G. Serum ECP and MPO are increased during exacerbations of chronic bronchitis with airway obstruction. Biomed Pharmacother. 2000;54(5):274-278.

doi: https://doi.org/10.1016/S0753-3322(00)80071-2

63. Crooks SW, Bayley DL, Hill SL, Stockley RA. Bronchial inflammation in acute bacterial exacerbations of chronic bronchitis: the role of leukotriene B4. Eur Respir J. 2000;15(2):274280. doi: https://doi.org/10.1034/j.1399-3003.2000.15b09.x

64. Aaron SD, Angel JB, Lunau M, et al. Granulocyte inflammatory markers and airway infection during acute exacerbation of chronic obstructive pulmonary disease. Am J Respir Crit Care Med. 2001;163(2):349-355.

doi: https://doi.org/10.1164/ajrccm.163.2.2003122

65. Churg A, Marshall CV, Sin DD, et al. Late intervention with a myeloperoxidase inhibitor stops progression of experimental chronic obstructive pulmonary disease. Am J Respir Crit Care Med. 2012;185(1):34-43.

doi: https://doi.org/10.1164/rccm.201103-04680C

66. Wang Y, Branicky R, Noe A, Hekimi S. Superoxide dismutases: Dual roles in controlling ROS damage and regulating ROS signaling. J Cell Biol. 2018;217(6):1915-1928. doi: https://doi.org/10.1083/jcb.201708007

67. Kinnula VL, Crapo JD. Superoxide dismutases in the lung and human lung diseases. Am J Respir Crit Care Med. 2003;167(12):1600-1619.

doi: https://doi.org/10.1164/rccm.200212-1479SO

68. Comhair SA, Xu W, Ghosh S, et al. Superoxide dismutase inactivation in pathophysiology of asthmatic airway remodeling and reactivity. Am J Pathol. 2005;166(3):663-674. doi: https://doi.org/10.1016/S0002-9440(10)62288-2

69. Arcaroli JJ, Hokanson JE, Abraham E, et al. Extracellular superoxide dismutase haplotypes are associated with acute lung injury and mortality. Am J Respir Crit Care Med. 2009;179(2):105112. doi: https://doi.org/10.1164/rccm.200710-1566OC 
70. Gao F, Koenitzer JR, Tobolewski JM, et al. Extracellular superoxide dismutase inhibits inflammation by preventing oxidative fragmentation of hyaluronan. $J$ Biol Chem. 2008;283(10):6058-6066.

doi: https://doi.org/10.1074/jbc.M709273200

71. Yao H, Arunachalam G, Hwang JW, et al. Extracellular superoxide dismutase protects against pulmonary emphysema by attenuating oxidative fragmentation of ECM. Proc Natl Acad Sci U S A. 2010;107(35):15571-15576. doi: https://doi.org/10.1073/pnas.1007625107

72. Break TJ, Witter AR, Indramohan M, Mummert ME, Dory L, Berg RE. Extracellular superoxide dismutase enhances recruitment of immature neutrophils to the liver. Infect Immun. 2016;84(12):3302-3312.

doi: https://doi.org/10.1128/IAI.00603-16

73. Alonso MR, Anesini C. Clinical evidence of increase in hair growth and decrease in hair loss without adverse reactions promoted by the commercial lotion ECOHAIR(R). Skin Pharmacol Physiol. 2017;30(1):46-54.

doi: https://doi.org/10.1159/000455958

74. Heck DE, Shakarjian M, Kim HD, Laskin JD, Vetrano AM. Mechanisms of oxidant generation by catalase. Ann N Y Acad Sci. 2010;1203(1):120-125. doi: https://doi.org/10.1111/j.1749-6632.2010.05603.x

75. Godic A, Poljsak B, Adamic M, Dahmane R. The role of antioxidants in skin cancer prevention and treatment. Oxid Med Cell Longev. 2014;860479.

doi: https://doi.org/10.1155/2014/860479

76. Kaarteenaho-Wiik R, Kinnula VL. Distribution of antioxidant enzymes in developing human lung, respiratory distress syndrome, and bronchopulmonary dysplasia. J Histochem Cytochem. 2004;52(9):1231-1240.

doi: https://doi.org/10.1369/jhc.4A6291.2004

77. Ghosh S, Janocha AJ, Aronica MA, et al. Nitrotyrosine proteome survey in asthma identifies oxidative mechanism of catalase inactivation. J Immunol. 2006;176(9):5587-5597.

doi: https://doi.org/10.4049/jimmunol.176.9.5587

78. Betsuyaku T, Fuke S, Inomata T, et al. Bronchiolar epithelial catalase is diminished in smokers with mild COPD. Eur Respir J. 2013;42(1):42-53.

doi: https://doi.org/10.1183/09031936.00058912

79. Zmijewski JW, Lorne E, Zhao X, et al. Antiinflammatory effects of hydrogen peroxide in neutrophil activation and acute lung injury. Am J Respir Crit Care Med. 2009;179(8):694-704. doi: https://doi.org/10.1164/rccm.200806-851OC

80. Rhee SG, Yang KS, Kang SW, Woo HA, Chang TS. Controlled elimination of intracellular $\mathrm{H}(2) \mathrm{O}(2)$ : regulation of peroxiredoxin, catalase, and glutathione peroxidase via posttranslational modification. Antioxid Redox Signal. 2005;7(56):619-626. doi: https://doi.org/10.1089/ars.2005.7.619
81. Ho YS, Magnenat JL, Bronson RT, et al. Mice deficient in cellular glutathione peroxidase develop normally and show no increased sensitivity to hyperoxia. J Biol Chem. 1997;272(26):16644-16651. doi: https://doi.org/10.1074/jbc.272.26.16644

82. Duong C, Seow HJ, Bozinovski S, Crack PJ, Anderson GP, Vlahos R. Glutathione peroxidase- 1 protects against cigarette smoke-induced lung inflammation in mice. Am J Physiol Lung Cell Mol Physiol. 2010;299(3):L425-433.

doi: https://doi.org/10.1152/ajplung.00038.2010

83. Yatmaz S, Seow HJ, Gualano RC, et al. Glutathione peroxidase-1 reduces influenza $\mathrm{A}$ virus-induced lung inflammation. Am J Respir Cell Mol Biol. 2013;48(1):17-26. doi: https://doi.org/10.1165/rcmb.2011-0345OC

84. Bozinovski S, Seow HJ, Crack PJ, Anderson GP, Vlahos R. Glutathione peroxidase-1 primes pro-inflammatory cytokine production after LPS challenge in vivo. PLoS One. 2012;7(3):e33172.

doi: https://doi.org/10.1371/journal.pone.0033172

85. Won HY, Sohn JH, Min HJ, et al. Glutathione peroxidase 1 deficiency attenuates allergen-induced airway inflammation by suppressing Th2 and Th17 cell development. Antioxid Redox Signal. 2010;13(5):575-587.

doi: https://doi.org/10.1089/ars.2009.2989

86. Dittrich AM, Meyer HA, Krokowski M, et al. Glutathione peroxidase-2 protects from allergen-induced airway inflammation in mice. Eur Respir J. 2010;35(5):1148-1154. doi: https://doi.org/10.1183/09031936.00026108

87. Singh A, Rangasamy T, Thimmulappa RK, et al. Glutathione peroxidase 2, the major cigarette smoke-inducible isoform of GPX in lungs, is regulated by Nrf2. Am J Respir Cell Mol Biol. 2006;35(6):639-650. doi: https://doi.org/10.1165/rcmb.2005-03250C

88. Avissar N, Finkelstein JN, Horowitz S, et al. Extracellular glutathione peroxidase in human lung epithelial lining fluid and in lung cells. Am J Physiol. 1996;270(2 Pt 1):L173-182. doi: https://doi.org/10.1152/ajplung.1996.270.2.L173

89. Comhair SA, Erzurum SC. The regulation and role of extracellular glutathione peroxidase. Antioxid Redox Signal. 2005;7(1-2):7279. doi: https://doi.org/10.1089/ars.2005.7.72

90. Schneider M, Forster H, Boersma A, et al. Mitochondrial glutathione peroxidase 4 disruption causes male infertility. FASEB J. 2009;23(9):3233-3242.

doi: https://doi.org/10.1096/f.09-132795

91. Yant LJ, Ran Q, Rao L, et al. The selenoprotein GPX4 is essential for mouse development and protects from radiation and oxidative damage insults. Free Radic Biol Med. 2003;34(4):496502. doi: https://doi.org/10.1016/S0891-5849(02)01360-6 
92. Vibhuti A, Arif E, Deepak D, Singh B, Qadar Pasha MA. Correlation of oxidative status with BMI and lung function in COPD. Clin Biochem. 2007;40(13-14):958-963. doi: https://doi.org/10.1016/j.clinbiochem.2007.04.020

93. Finkel T. Signal transduction by reactive oxygen species. J Cell Biol. 2011;194(1):7-15. doi: https://doi.org/10.1083/jcb.201102095

94. Patel P, Chatterjee S. Peroxiredoxin6 in endothelial signaling. Antioxidants (Basel). 2019;8(3). doi: https://doi.org/10.3390/antiox8030063

95. Elko EA, Cunniff B, Seward DJ, et al. Peroxiredoxins and beyond; redox systems regulating lung physiology and disease. Antioxid Redox Signal. 2019.

doi: https://doi.org/10.1089/ars.2019.7752

96. Mironczuk-Chodakowska I, Witkowska AM, Zujko ME. Endogenous non-enzymatic antioxidants in the human body. Adv Med Sci. 2018;63(1):68-78.

doi: https://doi.org/10.1016/j.advms.2017.05.005

97. Dubick MA, Barr JL, Keen CL, Atkins JL. Ceruloplasmin and hypoferremia: studies in burn and non-burn trauma patients. Antioxidants (Basel). 2015;4(1):153-169. doi: https://doi.org/10.3390/antiox4010153

98. Chapman AL, Mocatta TJ, Shiva S, et al. Ceruloplasmin is an endogenous inhibitor of myeloperoxidase. $J$ Biol Chem. 2013;288(9):6465-6477.

doi: https://doi.org/10.1074/jbc.M112.418970

99. Aruoma OI, Halliwell B, Hoey BM, Butler J. The antioxidant action of $\mathrm{N}$-acetylcysteine: its reaction with hydrogen peroxide, hydroxyl radical, superoxide, and hypochlorous acid. Free Radic Biol Med. 1989;6(6):593-597.

doi: https://doi.org/10.1016/0891-5849(89)90066-X

100. Moldeus P, Cotgreave IA, Berggren M. Lung protection by a thiol-containing antioxidant: N-acetylcysteine. Respiration. 1986;50 (Suppl 1):31-42. doi: https://doi.org/10.1159/000195086

101. Sanguinetti CM. N-acetylcysteine in COPD: why, how, and when? Multidiscip Respir Med. 2015;11:8.

doi: https://doi.org/10.1186/s40248-016-0039-2

102. Dekhuijzen PN, van Beurden WJ. The role for N-acetylcysteine in the management of COPD. Int J Chron Obstruct Pulmon Dis. 2006;1(2):99-106. doi: https://doi.org/10.2147/copd.2006.1.2.99

103. Pela R, Calcagni AM, Subiaco S, Isidori P, Tubaldi A, Sanguinetti $\mathrm{CM}$. N-acetylcysteine reduces the exacerbation rate in patients with moderate to severe COPD. Respiration. 1999;66(6):495-500. doi: https://doi.org/10.1159/000029447
104. Zheng JP, Wen FQ, Bai CX, et al. Twice daily N-acetylcysteine $600 \mathrm{mg}$ for exacerbations of chronic obstructive pulmonary disease (PANTHEON): a randomised, double-blind placebocontrolled trial. Lancet Respir Med. 2014;2(3):187-194. doi: https://doi.org/10.1016/S2213-2600(13)70286-8

105. Fowdar K, Chen $\mathrm{H}$, He Z, et al. The effect of $\mathrm{N}$-acetylcysteine on exacerbations of chronic obstructive pulmonary disease: A metaanalysis and systematic review. Heart Lung. 2017;46(2):120-128. doi: https://doi.org/10.1016/j.hrtlng.2016.12.004

106. Cazzola M, Matera MG. N-acetylcysteine in COPD may be beneficial, but for whom? Lancet Respir Med. 2014;2(3):166-167. doi: https://doi.org/10.1016/S2213-2600(13)70294-7

107. Hwang C, Sinskey AJ, Lodish HF. Oxidized redox state of glutathione in the endoplasmic reticulum. Science. 1992;257(5076): 1496-1502. doi: https://doi.org/10.1126/science.1523409

108. Mullineaux PM, Rausch T. Glutathione, photosynthesis and the redox regulation of stress-responsive gene expression. Photosynth Res. 2005;86(3):459-474. doi: https://doi.org/10.1007/s11120-005-8811-8

109. Moinova HR, Mulcahy RT. Up-regulation of the human gamma-glutamylcysteine synthetase regulatory subunit gene involves binding of Nrf-2 to an electrophile responsive element. Biochem Biophys Res Commun. 1999;261(3):661-668. doi: https://doi.org/10.1006/bbrc.1999.1109

110. Wild AC, Moinova HR, Mulcahy RT. Regulation of gammaglutamylcysteine synthetase subunit gene expression by the transcription factor Nrf2. J Biol Chem. 1999;274(47):3362733636. doi: https://doi.org/10.1074/jbc.274.47.33627

111. Chanas SA, Jiang Q, McMahon M, et al. Loss of the Nrf2 transcription factor causes a marked reduction in constitutive and inducible expression of the glutathione S-transferase Gsta1, Gsta2, Gstm1, Gstm2, Gstm3 and Gstm4 genes in the livers of male and female mice. Biochem J. 2002;365(Pt 2):405-416. doi: https://doi.org/10.1042/bj20020320

112. Lillig $\mathrm{CH}$, Berndt $\mathrm{C}$, Vergnolle $\mathrm{O}$, et al. Characterization of human glutaredoxin 2 as iron-sulfur protein: a possible role as redox sensor. Proc Natl Acad Sci U S A. 2005;102(23):8168-8173. doi: https://doi.org/10.1073/pnas.0500735102

113. Aquilano K, Baldelli S, Ciriolo MR. Glutathione: new roles in redox signaling for an old antioxidant. Front Pharmacol. 2014;5:196. doi: https://doi.org/10.3389/fphar.2014.00196

114. Tonelli C, Chio IIC, Tuveson DA. Transcriptional regulation by Nrf2. Antioxid Redox Signal. 2018;29(17):1727-1745. doi: https://doi.org/10.1089/ars.2017.7342

115. Ghezzi P. Role of glutathione in immunity and inflammation in the lung. Int J Gen Med. 2011;4:105-113. doi: https://doi.org/10.2147/IJGM.S15618 
116. Gould NS, Day BJ. Targeting maladaptive glutathione responses in lung disease. Biochem Pharmacol. 2011;81(2):187-193. doi: https://doi.org/10.1016/j.bcp.2010.10.001

117. Borok Z, Buhl R, Grimes GJ, et al. Effect of glutathione aerosol on oxidant-antioxidant imbalance in idiopathic pulmonary fibrosis. Lancet. 1991;338(8761):215-216. doi: https://doi.org/10.1016/0140-6736(91)90350-X

118. Marrades RM, Roca J, Barbera JA, de Jover L, MacNee W, Rodriguez-Roisin R. Nebulized glutathione induces bronchoconstriction in patients with mild asthma. Am J Respir Crit Care Med. 1997;156(2 Pt 1):425-430.

doi: https://doi.org/10.1164/ajrccm.156.2.9611001

119. Prousky J. The treatment of pulmonary diseases and respiratoryrelated conditions with inhaled (nebulized or aerosolized) glutathione. Evid Based Complement Alternat Med. 2008;5(1):2735. doi: https://doi.org/10.1093/ecam/nem040

120. Lopez-Lluch G, Rodriguez-Aguilera JC, Santos-Ocana C, Navas P. Is coenzyme $Q$ a key factor in aging? Mech Ageing Dev. 2010;131(4):225-235.

doi: https://doi.org/10.1016/j.mad.2010.02.003

121. Battino M, Gorini A, Villa RF, et al. Coenzyme $Q$ content in synaptic and non-synaptic mitochondria from different brain regions in the ageing rat. Mech Ageing Dev. 1995;78(3):173-187. doi: https://doi.org/10.1016/0047-6374(94)01535-T

122. Beyer RE, Burnett BA, Cartwright KJ, et al. Tissue coenzyme $Q$ (ubiquinone) and protein concentrations over the life span of the laboratory rat. Mech Ageing Dev. 1985;32(2-3):267-281. doi: https://doi.org/10.1016/0047-6374(85)90085-5

123. Kalen A, Appelkvist EL, Dallner G. Age-related changes in the lipid compositions of rat and human tissues. Lipids. 1989;24(7):579-584.

doi: https://doi.org/10.1007/BF02535072

124. Turunen M, Appelkvist EL, Sindelar P, Dallner G. Blood concentration of coenzyme $Q(10)$ increases in rats when esterified forms are administered. J Nutr. 1999;129(12):21132118.

125. De Benedetto F, Pastorelli R, Ferrario M, et al. Supplementation with Qter and creatine improves functional performance in COPD patients on long term oxygen therapy. Respir Med. 2018;142:86-93. doi: https://doi.org/10.1016/j.rmed.2018.08.002

126. Fan L, Feng Y, Chen GC, Qin LQ, Fu CL, Chen LH. Effects of coenzyme Q10 supplementation on inflammatory markers: a systematic review and meta-analysis of randomized controlled trials. Pharmacol Res. 2017;119:128-136. doi: https://doi.org/10.1016/j.phrs.2017.01.032

127. Hernandez-Camacho JD, Bernier M, Lopez-Lluch G, Navas P. Coenzyme Q10 supplementation in aging and disease. Front Physiol. 2018;9:44.

doi: https://doi.org/10.3389/fphys.2018.00044
128. Ames BN, Cathcart R, Schwiers E, Hochstein P. Uric acid provides an antioxidant defense in humans against oxidant- and radical-caused aging and cancer: a hypothesis. Proc Natl Acad Sci U S A. 1981;78(11):6858-6862.

doi: https://doi.org/10.1073/pnas.78.11.6858

129. Fabbrini E, Serafini M, Colic Baric I, Hazen SL, Klein S. Effect of plasma uric acid on antioxidant capacity, oxidative stress, and insulin sensitivity in obese subjects. Diabetes. 2014;63(3):976981. doi: https://doi.org/10.2337/db13-1396

130. Klein BE, Klein R, Lee KE. Components of the metabolic syndrome and risk of cardiovascular disease and diabetes in Beaver Dam. Diabetes Care. 2002;25(10):1790-1794. doi: https://doi.org/10.2337/diacare.25.10.1790

131. Bartziokas K, Papaioannou AI, Loukides S, et al. Serum uric acid as a predictor of mortality and future exacerbations of COPD. Eur Respir J. 2014;43(1):43-53. doi: https://doi.org/10.1183/09031936.00209212

132. Kahnert K, Alter P, Welte T, et al. Uric acid, lung function, physical capacity and exacerbation frequency in patients with COPD: a multi-dimensional approach. Respir Res. 2018;19(1):110. doi: https://doi.org/10.1186/s12931-018-0815-y

133. Pandi-Perumal SR, Trakht I, Srinivasan V, et al. Physiological effects of melatonin: role of melatonin receptors and signal transduction pathways. Prog Neurobiol. 2008;85(3):335-353. doi: https://doi.org/10.1016/j.pneurobio.2008.04.001

134. Hardeland R, Pandi-Perumal SR. Melatonin, a potent agent in antioxidative defense: actions as a natural food constituent, gastrointestinal factor, drug and prodrug. Nutr Metab (Lond). 2005;2:22. doi: https://doi.org/10.1186/1743-7075-2-22

135. Tan DX, Manchester LC, Reiter RJ, Qi WB, Karbownik M, Calvo JR. Significance of melatonin in antioxidative defense system: reactions and products. Biol Signals Recept. 2000;9(3-4):137-159. doi: https://doi.org/10.1159/000014635

136. Torres F, Gonzalez-Candia A, Montt C, et al. Melatonin reduces oxidative stress and improves vascular function in pulmonary hypertensive newborn sheep. J Pineal Res. 2015;58(3):362-373. doi: https://doi.org/10.1111/jpi.12222

137. Tsai SC. Chronic obstructive pulmonary disease and sleep related disorders. Curr Opin Pulm Med. 2017;23(2):124-128. doi: https://doi.org/10.1097/MCP.0000000000000351

138. Kelly FJ, Mudway IS. Protein oxidation at the air-lung interface. Amino Acids. 2003;25(3-4):375-396.

doi: https://doi.org/10.1007/s00726-003-0024-x

139. Birben E, Sahiner UM, Sackesen C, Erzurum S, Kalayci O. Oxidative stress and antioxidant defense. World Allergy Organ J. 2012;5(1):9-19.

doi: https://doi.org/10.1097/WOX.0b013e3182439613 
140. Medina-Navarro R, Duran-Reyes G, Diaz-Flores M, Vilar-Rojas C. Protein antioxidant response to the stress and the relationship between molecular structure and antioxidant function. PLoS One. 2010;5(1):e8971.

doi: https://doi.org/10.1371/journal.pone.0008971

141. Wayner DD, Burton GW, Ingold KU, Locke S. Quantitative measurement of the total, peroxyl radical-trapping antioxidant capability of human blood plasma by controlled peroxidation. The important contribution made by plasma proteins. FEBS Lett. 1985;187(1):33-37.

doi: https://doi.org/10.1016/0014-5793(85)81208-4

142. Quinlan GJ, Martin GS, Evans TW. Albumin: biochemical properties and therapeutic potential. Hepatology. 2005;41(6):1211-1219. doi: https://doi.org/10.1002/hep.20720

143. Otagiri M, Chuang VT. Pharmaceutically important pre- and posttranslational modifications on human serum albumin. Biol Pharm Bull. 2009;32(4):527-534.

doi: https://doi.org/10.1248/bpb.32.527

144. Taverna M, Marie AL, Mira JP, Guidet B. Specific antioxidant properties of human serum albumin. Ann Intensive Care. 2013;3(1):4. doi: https://doi.org/10.1186/2110-5820-3-4

145. Colombo G, Clerici M, Giustarini D, Rossi R, Milzani A, DalleDonne I. Redox albuminomics: oxidized albumin in human diseases. Antioxid Redox Signal. 2012;17(11):1515-1527. doi: https://doi.org/10.1089/ars.2012.4702

146. Turell L, Botti H, Carballal S, et al. Reactivity of sulfenic acid in human serum albumin. Biochemistry. 2008;47(1):358-367. doi: https://doi.org/10.1021/bi701520y

147. McGuinness AJ, Sapey E. Oxidative stress in COPD: sources, markers, and potential mechanisms. J Clin Med. 2017;6(2):21. doi: https://doi.org/10.3390/jcm6020021

148. Johnson D, Travis J. The oxidative inactivation of human alpha-1 proteinase inhibitor. Further evidence for methionine at the reactive center. J Biol Chem. 1979;254(10):4022-4026. doi: https://www.ncbi.nlm.nih.gov/pubmed/312289

149. Levine RL, Mosoni L, Berlett BS, Stadtman ER. Methionine residues as endogenous antioxidants in proteins. Proc Natl Acad Sci U S A. 1996;93(26):15036-15040. doi: https://doi.org/10.1073/pnas.93.26.15036

150. Stockley RA. Alpha-1antitrypsin: a polyfunctional protein? Lancet Respir Med. 2015;3(5):341-343. doi: https://doi.org/10.1016/S2213-2600(15)00094-6

151. Carp H, Miller F, Hoidal JR, Janoff A. Potential mechanism of emphysema: alpha-1 proteinase inhibitor recovered from lungs of cigarette smokers contains oxidized methionine and has decreased elastase inhibitory capacity. Proc Natl Acad Sci U S A. 1982;79(6):2041-2045.

doi: https://doi.org/10.1073/pnas.79.6.2041
152. Taggart C, Cervantes-Laurean D, Kim G, et al. Oxidation of either methionine 351 or methionine 358 in alpha- 1 antitrypsin causes loss of anti-neutrophil elastase activity. $J$ Biol Chem. 2000;275(35):27258-27265. doi: https://doi.org/10.1074/jbc.M004850200

153. Moraga F, Janciauskiene S. Activation of primary human monocytes by the oxidized form of alpha-1 antitrypsin. $J$ Biol Chem. 2000;275(11):7693-7700. doi: https://doi.org/10.1074/jbc.275.11.7693

154. Li Z, Alam S, Wang J, Sandstrom CS, Janciauskiene S, Mahadeva R. Oxidized alpha-1 antitrypsin stimulates the release of monocyte chemotactic protein-1 from lung epithelial cells: potential role in emphysema. Am J Physiol Lung Cell Mol Physiol. 2009;297(2):L388-400. doi: https://doi.org/10.1152/ajplung.90373.2008

155. Wright JL, Farmer SG, Churg A. A neutrophil elastase inhibitor reduces cigarette smoke-induced remodelling of lung vessels. Eur Respir J. 2003;22(1):77-81. doi: https://doi.org/10.1183/09031936.03.00095703

156. Subramaniyam D, Virtala R, Pawlowski K, et al. TNF-alphainduced self-expression in human lung endothelial cells is inhibited by native and oxidized alpha1-antitrypsin. Int $J$ Biochem Cell Biol. 2008;40(2):258-271. doi: https://doi.org/10.1016/j.biocel.2007.07.016

157. Jedicke N, Struever N, Aggrawal N, et al. Alpha-1 antitrypsin inhibits acute liver failure in mice. Hepatology. 2014;59(6):22992308. doi: https://doi.org/10.1002/hep.27024

158. Siebers K, Fink B, Zakrzewicz A, et al. Alpha-1 antitrypsin inhibits ATP-mediated release of interleukin-1beta via CD36 and nicotinic acetylcholine receptors. Front Immunol. 2018;9:877. doi: https://doi.org/10.3389/fimmu.2018.00877

159. Panyutich AV, Hiemstra PS, van Wetering S, Ganz T. Human neutrophil defensin and serpins form complexes and inactivate each other. Am J Respir Cell Mol Biol. 1995;12(3):351-357. doi: https://doi.org/10.1165/ajrcmb.12.3.7873202

160. Spencer LT, Paone G, Krein PM, Rouhani FN, Rivera-Nieves $\mathrm{J}$, Brantly ML. Role of human neutrophil peptides in lung inflammation associated with alpha-1antitrypsin deficiency. Am J Physiol Lung Cell Mol Physiol. 2004;286(3):L514-520. doi: https://doi.org/10.1152/ajplung.00099.2003

161. Wencker M, Brantly ML. Cytotoxic concentrations of alphadefensins in the lungs of individuals with alpha-1 antitrypsin deficiency and moderate to severe lung disease. Cytokine. 2005;32(1):1-6. doi: https://doi.org/10.1016/j.cyto.2005.06.003

162. Frenzel E, Wrenger S, Immenschuh S, et al. Acute-phase protein alpha-1 antitrypsin-a novel regulator of angiopoietin-like protein 4 transcription and secretion. J Immunol. 2014;192(11):53545362. doi: https://doi.org/10.4049/jimmunol.1400378 
163. Karnaukhova E, Krupnikova SS, Rajabi M, Alayash AI. Heme binding to human alpha-1 proteinase inhibitor. Biochim Biophys Acta. 2012;1820(12):2020-2029. doi: https://doi.org/10.1016/j.bbagen.2012.09.012

164. Tiriveedhi V, Banan B, Deepti S, et al. Role of defensins in the pathogenesis of chronic lung allograft rejection. Hum Immunol. 2014;75(4):370-377.

doi: https://doi.org/10.1016/j.humimm.2013.12.014

165. Miyamoto Y, Akaike T, Maeda H. S-nitrosylated human alpha (1)-protease inhibitor. Biochim Biophys Acta. 2000;1477(1-2):9097. doi: https://doi.org/10.1016/S0167-4838(99)00264-2

166. Janciauskiene S, Welte T. Well-known and less well-known functions of alpha-1 antitrypsin. Its role in chronic obstructive pulmonary disease and other disease developments. Ann Am Thorac Soc. 2016;13(Suppl 4):S280-288.

doi: https://doi.org/10.1513/AnnalsATS.201507-468KV

167. Kaner Z, Engelman R, Schuster R, et al. S-Nitrosylation of a1-antitrypsin triggers macrophages toward inflammatory phenotype and enhances intra-cellular bacteria elimination. Front Immunol. 2019;10(590).

doi: https://doi.org/10.3389/fimmu.2019.00590

168. Janciauskiene S, Wrenger S, Immenschuh S, et al. The multifaceted effects of alpha-1 antitrypsin on neutrophil functions. Front Pharmacol. 2018;9:341. doi: https://doi.org/10.3389/fphar.2018.00341

169. Kuscuoglu D, Janciauskiene S, Hamesch K, Haybaeck J, Trautwein C, Strnad P. Liver - master and servant of serum proteome. J Hepatol. 2018;69(2):512-524. doi: https://doi.org/10.1016/j.jhep.2018.04.018

170. Marcus NY, Blomenkamp K, Ahmad M, Teckman JH. Oxidative stress contributes to liver damage in a murine model of alpha-1 antitrypsin deficiency. Exp Biol Med (Maywood). 2012;237(10):1163-1172.

doi: https://doi.org/10.1258/ebm.2012.012106

171. Kelly E, Greene CM, Carroll TP, McElvaney NG, O’Neill SJ. Selenoprotein S/SEPS1 modifies endoplasmic reticulum stress in Z variant alpha-1antitrypsin deficiency. J Biol Chem. 2009;284(25):16891-16897.

doi: https://doi.org/10.1074/jbc.M109.006288

172. Rudnick DA, Perlmutter DH. Alpha-1 antitrypsin deficiency: a new paradigm for hepatocellular carcinoma in genetic liver disease. Hepatology. 2005;42(3):514-521. doi: https://doi.org/10.1002/hep.20815

173. Sanchez-Valle V, Chavez-Tapia NC, Uribe M, Mendez-Sanchez N. Role of oxidative stress and molecular changes in liver fibrosis: a review. Curr Med Chem. 2012;19(28):4850-4860. doi: https://doi.org/10.2174/092986712803341520
174. Li S, Tan HY, Wang N, et al. The role of oxidative stress and antioxidants in liver diseases. Int J Mol Sci. 2015;16(11):2608726124. doi: https://doi.org/10.3390/ijms 161125942

175. Barnes PJ, Shapiro SD, Pauwels RA. Chronic obstructive pulmonary disease: molecular and cellular mechanisms. Eur Respir J. 2003;22(4):672-688. doi: https://doi.org/10.1183/09031936.03.00040703

176. Deslee G, Woods JC, Moore C, et al. Oxidative damage to nucleic acids in severe emphysema. Chest. 2009;135(4):965-974. doi: https://doi.org/10.1378/chest.08-2257

177. Owen CA. Proteinases and oxidants as targets in the treatment of chronic obstructive pulmonary disease. Proc Am Thorac Soc. 2005;2(4):373-394.

doi: https://doi.org/10.1513/pats.200504-029SR

178. Rahman I, Morrison D, Donaldson K, MacNee W. Systemic oxidative stress in asthma, COPD, and smokers. Am J Respir Crit Care Med. 1996;154(4 Pt 1):1055-1060. doi: https://doi.org/10.1164/ajrccm.154.4.8887607

179. Rahman I, Swarska E, Henry M, Stolk J, MacNee W. Is there any relationship between plasma antioxidant capacity and lung function in smokers and in patients with chronic obstructive pulmonary disease? Thorax. 2000;55(3):189-193. doi: https://doi.org/10.1136/thorax.55.3.189

180. van Antwerpen VL, Theron AJ, Richards GA, et al. Vitamin E, pulmonary functions, and phagocyte-mediated oxidative stress in smokers and nonsmokers. Free Radic Biol Med. 1995;18(5):935941. doi: https://doi.org/10.1016/0891-5849(94)00225-9

181. Zinellu E, Zinellu A, Fois AG, Carru C, Pirina P. Circulating biomarkers of oxidative stress in chronic obstructive pulmonary disease: a systematic review. Respir Res. 2016;17(1):150. doi: https://doi.org/10.1186/s 12931-016-0471-z

182. Massaro GD, Massaro D. Retinoic acid treatment abrogates elastase-induced pulmonary emphysema in rats. Nat Med. 1997;3(6):675-677. doi: https://doi.org/10.1038/nm0697-675

183. Mao JT, Goldin JG, Dermand J, et al. A pilot study of all-transretinoic acid for the treatment of human emphysema. Am J Respir Crit Care Med. 2002;165(5):718-723. doi: https://doi.org/10.1164/ajrccm.165.5.2106123

184. Konno K, Arai H, Motomiya M, et al. A biochemical study on glycosaminoglycans (mucopolysaccharides) in emphysematous and in aged lungs. Am Rev Respir Dis. 1982;126(5):797801.

185. Cantor JO, Cerreta JM, Armand G, Turino GM. Aerosolized hyaluronic acid decreases alveolar injury induced by human neutrophil elastase. Proc Soc Exp Biol Med. 1998;217(4):471-475. doi: https://doi.org/10.3181/00379727-217-44260 
186. Gocmen G, Gonul O, Oktay NS, Yarat A, Goker K. The antioxidant and anti-inflammatory efficiency of hyaluronic acid after third molar extraction. J Craniomaxillofac Surg. 2015;43(7):10331037. doi: https://doi.org/10.1016/j.jcms.2015.04.022

187. Turino GM, Ma S, Lin YY, Cantor JO. The therapeutic potential of hyaluronan in COPD. Chest. 2018;153(4):792-798. doi: https://doi.org/10.1016/j.chest.2017.12.016

188. Escribano A, Amor M, Pastor S, et al. Decreased glutathione and low catalase activity contribute to oxidative stress in children with alpha-1 antitrypsin deficiency. Thorax. 2015;70(1):82-83. doi: https://doi.org/10.1136/thoraxjnl-2014-205898

189. Sandhaus RA. Alpha-1 antitrypsin deficiency-6: new and emerging treatments for alpha- 1 antitrypsin deficiency. Thorax. 2004;59(10):904-909.

doi: https://doi.org/10.1136/thx.2003.006551 